\title{
Influence of Combination of Quail Egg Yolk and Coconut Water on the Frozen Semen Quality of Simmental (Bos taurus L.)
}

\author{
Ramadhan Sumarmin $^{1}$, Rizki Siswanto ${ }^{2}$, Nadyatul Khaira Huda ${ }^{3}$, Elsa Yuniarti ${ }^{4}$ \\ 1, 2, 4 Department of Biology, Faculty of Mathematics and Natural Sciences, Padang State University, \\ Jl. Prof. Dr. Hamka, Air Tawar Barat, Padang, West Sumatera, Indonesia \\ ${ }^{3}$ Department of Biology, Faculty of Mathematics and Natural Sciences, Andalas University, \\ Jl. Prof. Dr. M. Hatta, Limau Manis, Padang, West Sumatera, Indonesia
}

\begin{abstract}
West Sumatera have artificial insemination program to improve production, and quality of cattle, but there are obstacles, such as the provision of diluents semen frozen by the government less than the optimum. So that the availability of diluents is insufficient to produce frozen semen. It is Necessary to find suplement diluents there for more practical, economical, and more importantly are Able to maintain the quality of frozen semen of cattle. This study aims to determine the effect of the combination of quail egg yolk and coconut water as diluents to the quality of frozen semen of Simmental cattle (Bos taurus L.). This research has been conducted in June-September 2016 in the Laboratory of Artificial Insemination (BIB) Tuah Sakato, Payakumbuah, used Completely Randomized Design with 4 treatments and 6 repetitions. The treatment as follows: andromed (Control), 25\% yolk quail $+66 \%$ coconut water $+8 \%$ glycerol $+0.1 \%$ penicillin-streptomycin $+0: 08 \%+0.82 \%$ aquabidest $(P 1), 45,5 \%$ egg yolk quail $+45.5 \%$ coconut water + $8 \%$ glycerol $+0.1 \%$ penicillin-streptomycin $+0.08 \%+0.82 \%$ aquabidest $(P 2), 66 \%$ yolk quail $+25 \%$ coconut water $+8 \%$ glycerol + $0.1 \%$ penicillin-streptomycin $+0: 08 \%+0.82 \%$ aquabidest $(P 3)$. The result showed percentage of viability controls $72.66 \%$, $70.50 \%$ P1, $P 267.16 \%, 65.50 \%$ P3. The mean percentage of frozen semen motility control $71.33 \%$, 69.66\% P1, P2 65.00\%, 61.66\% P3.The percentage of average normality controls $85.50 \%, 84.33 \%$ P1, P2 $84.66 \%$, $84.16 \%$ P3. Based on the results of this study concluded that the combination of quail egg yolk and coconut water affects the quality of frozen semen of Simmental cattle (Bos taurus L.).
\end{abstract}

Keywords: yolk quail eggs, coconut water, frozen Semen quality, Simmental bull

\section{Introduction}

The livestock sector has an important role in the life and development of human resources in Indonesia. Improvement of public welfare will be followed by an increase in consumption of livestock products, thus it helped drive the economy in the livestock sub-sector [1]. According [2] problems faced by Indonesia in the field of animal husbandry is still low productivity and genetic quality of livestock. The factors causing low productivity of livestock in Indonesia, which is not optimal maintenance management[3]. These problems can be overcome through the application of technology Artificial insemination (AI).

IB success is determined by several factors, one of which is the quality of semen used. Semen quality include $\mathrm{pH}$, color, viability, motility and concentration [4]. Every cows have semen quality varies depending on the age, condition of livestock, libido and nations.

One of the factors that also affect the quality of sperm in semen is frozen pengencer. Pengencer use functions ensure the physical and chemical requirements of spermatozoa so that sperm quality can be maintained, especially on the ability to capacitation [5]. Semen storage at low temperatures can damage sperm [6].

Terms of diluent used is inexpensive, simple, practical made, contains elements that are almost the same physical and chemical properties of cement, does not contain toxic substances both on sperm and genital tract of the female, retaining and do not limit the power of fertilization of sperm, and allow sperm votes after dilution. Diluent present such as andromed can not meet all these requirements both in terms of price and in terms of the availability of diluent, so it requires a combination of diluents such as milk, egg yolks and coconut water [6].

Quail eggs has been known to the public for consumption rumahan. Manfaat the nutrients contained in the quail eggs are not inferior to the nutrients contained in eggs when used as diluents semen. Air young coconut is a natural isotonic fluid that is widely used as replacement for lost body fluids and prevent poisoning especially mineral poisoning. According [7]. Coconut milk contains $0.2 \%$ protein, $0.15 \%$ fat, $7.27 \%$ carbohydrates, sugars, vitamins, electrolytes and hormones that cause this growth. Young coconut water is widely used as a diluent of cement especially cows and goat.

Simmental cattle is one of the nation's beef cattle that have rapid growth. Cows of this type has two functions, namely to produce milk and meat. Based on these advantages, many farmers in Indonesia who maintain Simmental cows to meet the high demand for beef for the community [8].

\section{Material and Methods}

The experiment was conducted in January 2016, in the Laboratory of Artificial Insemination (BIB) Tuah Sakato Payakumbuah. 


\section{International Journal of Science and Research (IJSR) \\ ISSN (Online): 2319-7064}

Index Copernicus Value (2016): 79.57 | Impact Factor (2015): 6.391

\subsection{Research Materials}

Materials were used that semen from bulls Simmental 3 years old are accommodated using an artificial vagina, then the egg yolk quail, penicillin and streptomycin, glycerol $8 \%$, aquabidest, as diluents, eosin $2 \%$ is used to view the viability of spermatozoa, coconut water, nitrogen $\left(-196^{\circ} \mathrm{C}\right)$.

\subsection{Research Methods}

This research used Complete Random Design (CRD) with 4 treatments and 6 repetitions. Implementation of research begins with a semen reservoir is then observed macroscopically and microscopically. If already qualified then continued with the process of freezing semen that has been diluted. Thawing process is performed after freezing semen for 24 hours in a container containing liquid nitrogen.

\subsection{Data Analysis}

Data were analyzed using ANOVA test and continued with Duncan New Multiple Range Test (DNMRT) at $p<0.05$

\section{Results and Discussion}

\subsection{Semen Quality}

First step of this research was analized the quality of semen as sample. The result showed at table 1 below.

Table 1: Simmental Semen Quality

\begin{tabular}{|c|c|}
\hline Quality & Criteria/Value \\
\hline \multicolumn{2}{|c|}{ Macroscopic } \\
\hline Volume & $5 \mathrm{ml}$ \\
\hline Color & Beige \\
\hline Concistency & Thick \\
\hline \multicolumn{2}{|c|}{ Microscopic } \\
\hline Individual Motility & $80 \%$ \\
\hline Mass Movement & +++ \\
\hline Abnormality & $4 \%$ \\
\hline Viability & $78 \%$ \\
\hline
\end{tabular}

Description: +++ The mass movement of spermatozoa is moving waves of thick, dark, fast and accompanied rounds.

\subsubsection{Volume}

From macroscopic observation showed that semen volume Simmental cattle have $5 \mathrm{ml}$ after one penampungan.Sapi usually produces $5-6 \mathrm{ml}$ in one shelter. This is in accordance with the opinion of [9] which states that cattle semen volume ranges from 5-8 $\mathrm{ml}$ /ejaculate.

\subsubsection{Color}

Color of semen Simmental cattle on the macroscopic observation was beige. Beige is the normal color of Simmental cattle semen. Semen color depends on the type of cattle that accommodated it semen. According to [10] stated that several factors affect the color of semen as the level of arousal, ejaculation frequency, and quality of feed.

\section{$3.1 .3 \mathrm{pH}$}

Simmental cattle semen after macroscopically tested has a $\mathrm{pH}$ of 7. The $\mathrm{pH} 7$ is the normal $\mathrm{pH}$ of semen; this normality will assist in the process of cement in accordance with the opinion Freezing. According to [9] states that cattle semen $\mathrm{pH}$ between $6,4-7,8$.

\subsubsection{Individual Motility}

Motility individual semen Simmental cattle after microscopically examined and seen in elevated percentages of view can result in $80 \%$, where it is still within the range of opinions [11] which is between $50-80 \%$. Motility will be reduced if it is not immediately followed by a dilution process.

\subsubsection{Mass Movememt}

Microscopic Observation fresh semen during the study, obtained an average mass motility of spermatozoa is $+++(3)$. [6]. Very good "(+++)" can be seen surging, many, dark, thick, and active and fast moving. Good " $(++)$ " looks a little wave, thin, sparse, less clear and somewhat sluggish. Less good "(+)" if not visible wave but only the active individual movement progressive. Poor "(N / O )" when little or no individual movement.

\subsubsection{Abnormal Spermatozoa}

Simmental cattle semen abnormalities after microscopic examination showed the percentage value of $4 \%$. These results indicate that fresh semen of Simmental cows sampled have good quality because of the low percentage of abnormalities. High quality semen containing up to $5-15 \%$ of abnormal sperm [12].

\section{Semen Quality Post-thawing}

\subsection{Sperm Viability}

Table 2: Mean frozen semen viability value Simmental cattle $(\%)$

\begin{tabular}{|c|c|}
\hline Treatment & $\begin{array}{c}\text { Mean value of Simmental cattle frozen semen } \\
\text { viability }(\%)\end{array}$ \\
\hline Control & $72.66^{\mathrm{a}}$ \\
\hline P1 & $70.50^{\mathrm{b}}$ \\
\hline P2 & $67.16^{\mathrm{c}}$ \\
\hline P3 & $65.50^{\mathrm{d}}$ \\
\hline
\end{tabular}

Description: In the column the same number followed superscript letters differ significantly different at $p<0.05$ in Duncan test.

The percentage of viability which is higher than the diluent control P1 P2 and the percentage P3.Rataan approaching the average percentage of control is the diluent $\mathrm{P} 1$. P1 diluent containing $25 \%$ yolk quail $+66 \%$ coconut water $+8 \%$ glycerol $+0.1 \%$ penicillin $+0.08 \%+0.82 \%$ streptomycin aquabidest so that adequate nutrients needed spermatozoa and the buffer solution is still stable and still isotonic osmotic pressure.

In addition $25 \%$ of quail egg yolk has been able to protect the sperm membrane damage when the temperature decreases (cold shock)it is due to have a quail egg yolk lipoprotein and 


\section{International Journal of Science and Research (IJSR) \\ ISSN (Online): 2319-7064}

Index Copernicus Value (2016): 79.57 | Impact Factor (2015): 6.391

lecithin. Lipoprotein and lecithin will coat the semipermeable membrane so that the sperm cells are protected from temperature decreases. During the freezing process cement, the ice crystals that form will lead to increased electrolyte concentrations in cells that would dissolve the cell wall lipoprotein sheath spermatozoa, and the time thawing will change the permeability of the plasma membrane so that the sperm will die [9].

In addition $66 \%$ of young coconut water contains sucrose also suffice as a source of energy for spermatozoa. Viability of spermatozoa is affected by the need for nutrients.

Duncan's test results further showed a significant difference between control, P1, P2, and P3. However, the difference between the control with the diluent $\mathrm{P} 1$ is not too far so that $\mathrm{P} 1$ diluent containing $25 \%$ yolk quail $+66 \%$ coconut water + $8 \%$ glycerol $+0.1 \%$ penicillin $+0.08 \%+0.82 \%$ streptomycin, aquabidest better used as a diluent in order to maintain the life of a replacement cow spermatozoa containing andromed control (control). This study showed similar results with a previous study that combines duck egg yolk and coconut water. The $25 \%$ dilution of duck egg yolk and $75 \%$ coconut water is a combination of the most wellthinning to maintain abnormalities, viability and motility cow Bali [13]. Namun combine with duck egg yolk has a lower percentage of viability compared with researchers who combined with yellow quail eggs in this study.

\subsection{Motility}

Table 3: The mean value of Simmental cattle frozen semen motility (\%)

\begin{tabular}{|c|c|}
\hline Treatment & $\begin{array}{c}\text { Mean value of Simmental cattle } \\
\text { frozen semen motility (\%) }\end{array}$ \\
\hline Control & $71.33^{\mathrm{a}}$ \\
\hline P1 & $69.66^{\mathrm{a}}$ \\
\hline P2 & $65.00^{\mathrm{b}}$ \\
\hline P3 & $61.66^{\mathrm{c}}$ \\
\hline
\end{tabular}

Description: In the same column numbers followed by superscript letters differ significantly different at $p<0.05$ in Duncan test.

The mean value of the diluent treatment motility $\mathrm{P} 2$ and $\mathrm{P} 3$ is a very significant trend factors suspected lack or abundance of fructose and instability that can lower the $\mathrm{pH}$ buffer excessively. Minimal use egg yolks as much as 5\% of a diluent agent when directly used, while if the user will be saved yolk maximum of $20 \%$ of a diluent agent [9].

The mean value of the diluent $\mathrm{P} 2$ and $\mathrm{P} 3$ have motility percentage above $40 \%$ which still meets standar. [14]. states motile spermatozoa fertilization process requires approximately ten million spermatozoa, the spermatozoa requirements as standard insemination is $2,5 \times 107$ spermatozoa per straw with $40 \%$ motility. Nevertheless, these results indicate that the combination of a quail's egg yolk $25 \%+66 \%$ coconut water $+8 \%$ glycerol $+0.1 \%$ penicillin, streptomycin $+0.08 \%+0.82 \%$ aquabidestis a combination Palikwell as diluent for have a higher percentage motility compared diluent P2 and P3. The decrease in the percentage of progressive motility of spermatozoa may be due to the number of dead and become toxic to spermatozoa were still alive, so in general the quality is lowered [15]. It is showing motility and viability proportional and influence each other.

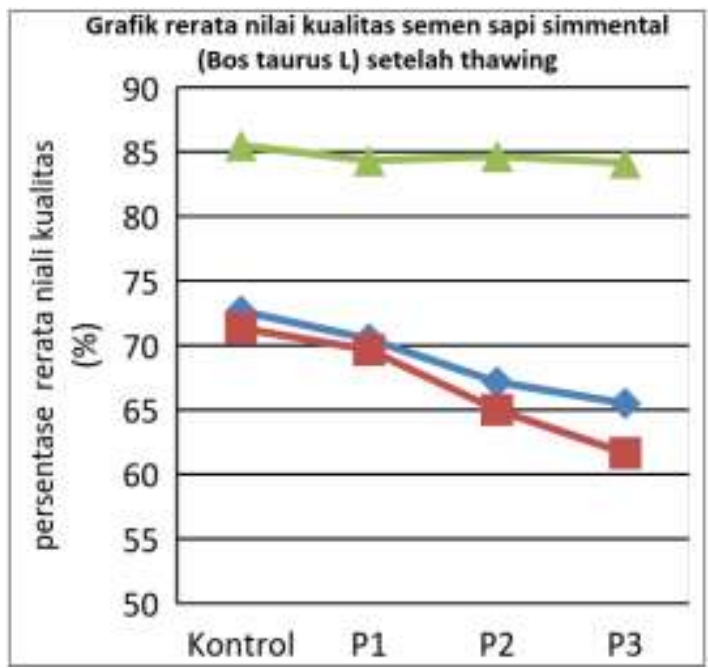

Figure 1: Percentage Quality of Semen Post Thawing

\subsection{Normality}

Table 4: The mean value of normality Simmental cattle frozen semen $(\%)$

\begin{tabular}{|c|c|}
\hline Treatment & Mean Simmental cattle sperm normality value (\%) \\
\hline Control & 85.50 \\
\hline P1 & 84.33 \\
\hline P2 & 84.66 \\
\hline P3 & 84.16 \\
\hline
\end{tabular}

Percentage of normality of spermatozoa after thawing at each perlakuanmenunjukkan that the combination of yellow telurpuyuh and coconut water does not affect the normality since the average normality ranges from $84-85 \%$, so the average abnormality of each diluent is 4-5\% [9] and [16]. This is in accordance with the recommended that during sperm abnormality has not reached $20 \%$ and not exceed the spermatozoa still in good condition and can be used for the IB program. According to [17] semen usually contains 5\% abnormal spermatozoa, fertility will not be interrupted until the abnormal level of $20 \%$ to $25 \%$. Abnormal spermatozoa showed progressive motility.

\section{Conclusions and Recommendations}

On these results it can be concluded that the combination of quail egg yolk and coconut water as a diluent influential in maintaining the viability, motility, and sperm normality Simmental cattle. Kombinasipengencer with a concentration of $25 \%$ yolk quail $+66 \%$ coconut water $+8 \%$ glycerol + $0.1 \%$ penicillin $+0.08 \%+0.82 \%$ streptomycin aquabidesta combination of diluent is able to maintain the quality of spermatozoa Simmental cattle(Bostaurus L .).

Suggestions To further research in order to better prepare the necessary tools so easy to do the research and get better results.

\section{Volume 6 Issue 12, December 2017 www.ijsr.net}




\section{International Journal of Science and Research (IJSR) \\ ISSN (Online): 2319-7064}

Index Copernicus Value (2016): 79.57 | Impact Factor (2015): 6.391

\section{References}

[1] Adhyatma, M. Nurul Isnaini, Nuryadi.2012.Pengaruh Body Weight on the Quality and Quantity of Semen Simmental Cattle. Poor R. Caves, Multinational Enterprise and Economic Analysis, Cambridge University Press, Cambridge, 1982. (book style)

[2] Hastuti, Dewi. 2008. The success rate of artificial insemination Beef Cattle Seen From Figures Conception And Service Per Conception.Journal of the Faculty of Agriculture, University of WahidHasyim.Mediagro vol.4. No.1.Hal 12-20. SemarangH.H. Crokell, "Specialization and International Competitiveness," in Managing the Multinational Subsidiary, H. Etemad and L. S, Sulude (eds.), Croom-Helm, London, 1986. (book chapter style)

[3] Kaunang, Dedy, Suyadi, Sri Wahjuningsih. 2012. Analysis of Litter Size, Weight Birth and Marriage Mating Results Weight Cattle Artificial Insemination Natural and Boer Goat and Peranakan Etawah (PE). Journal of Animal Science ofUB.Vol. 23.No. 3. 41-46. Poor

[4] Feradis. 2010. Biotechnology in Animal Reproduction.Bandung: Alfabeta

[5] Partodihardjo, S. 1992. Animal Reproduction Science Matter 3rd Faculty of Medicine and Veterinary,IPB.Jakarta: Pearl Source Wijaya

[6] Toelihere, MR. 1993. .Livestock Artifiscial Insemmination. Angkasa Bandung Press

[7] Susilawati, T. 2011. Spermatozoatology. Malang: Brawijaya University.

[8] Pratiwi, WC, L. Affandhy, D. Ratnawati. 2006. Pengaruh Old thawing on the Quality of Frozen Semen Cattle Limousin and Brahman.Journal of Animal Reproduction.Vol.11, No. 1, pages.48-52

[9] Garner, DL and ESE Hafez. 2000. Sperm and Seminal Plasma in Reproduction in FarmAnimals.Edited by ESE Hafez. $7^{\text {th }}$ edition. Lippincott Williams and Wilkins. Maryland, USA.

[10] Johnson, LA, KF Weitze, P. Fiser and WMC Maxwell. 2000. Storage of Boar Semen. J. Anim. Sci. 62: 143-172

[11] Hafez, ESE, 2002. Semen Evaluation in Reproductions in AnimalFarm. $7^{\text {th }}$ edition. Lippincott Williamsand Wilkins. Maryland, USA.

[12] Campbell, JR, KL Campbell, and MD Kenealy. 2003. Artficial Insemination. In: Animal Sciences $4^{\text {th }}$ ed. New York, Mc Graw-Hill.,

[13] Umbrella, R. 2015. The difference in composition Yellow Duck Egg and Coconut water as a diluent Semen on Sperm Quality Beef Bali Post Thawing.Skripsi. Medical School. Hasanuddin University.

[14] Susilawati, T., Suyadi, Nuryadi, Isnaini, N., and Wahyuningsih, S. 1993. Semen Quality Beef Cattle Fries Holland and Bali At Different Age and Weight. Research Report. UB's Faculty of AnimalHusbandry.Poor.

[15] Parera, F., Z. Prihatiny, DF Souhoka, and M. Rizal. 2009. Utilization of carrot juice as a diluent alternatives Bali bull epididymal spermatozoa. J. Indon.Trop.Anim. Agric. 34 (1): 50-56
[16] Arifiantini, L., TL Joseph, and Mary D. 2005 ${ }^{\text {b. Assess }}$ appeal frozen semen quality Holstein Friesian cattle using a diluent from a variety of artificial insemination centers in Indonesia. Animal Production 7 (3): 168-176

[17] Bearden, HJ and John W. Fuguay.Reston,1980. Applied Animal Reproduction

\section{Author Profile}

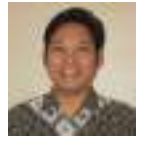

Ramadhan Sumarmin received the B.S. degree from Andalas University and M.S. degrees fron Bandung Institute of Technology in Biology in 1997 and 1999, respectively. During 2003- 2008, he get Doctor Program in University of Bogor Agricultural in Reproductive Biology. He now a lecturer at Universitas Negeri Padang 